\title{
Transmission of Hepatitis C Virus From a Mother to a Child Carrying IL28B Heterozygote rs8099917 Among Three Brothers: A Long-Term Follow-Up
}

\author{
Takafumi Saito ${ }^{\mathrm{a}, \mathrm{c}}$, Kei Mizuno ${ }^{\mathrm{a}}$, Tomohiro Katsumi ${ }^{\mathrm{a}}$, Kyoko Tomita ${ }^{\mathrm{a}}$, Chikako Sato ${ }^{\mathrm{a}}$, \\ Kazuo Okumoto ${ }^{\text {, }}$ Yuko Nishise ${ }^{a}$, Hisayoshi Watanabe ${ }^{a}$, Li Shao ${ }^{b}$, Yoshiyuki Ueno ${ }^{a}$
}

\begin{abstract}
Three male children were born every 2 years by spontaneous delivery from a mother infected with hepatitis $\mathrm{C}$ virus ( $\mathrm{HCV}$ ) genotype $2 \mathrm{~b}$, and all have been followed up after birth. The viral load in the serum of the mother was high before their deliveries, and anti-HCV antibody immunoglobulin $\mathrm{G}$, which is allowed to pass through placenta, was positive in the umbilical blood of all the children. Mother-to-child transmission of HCV was confirmed in the second son, who was positive for both anti-HCV antibody and serum HCV RNA when first examined 108 days after birth, but not in the other siblings. Persistent HCV genotype $2 b$ infection with mild elevation of the serum alanine aminotransferase level has been established in the second son for more than 14 years. The interleukin $28 B$ (IL28B) genotype (rs8099917) of the second son showed the TG heterozygote, which is unfavorable for viral clearance, and this may predict persistent $\mathrm{HCV}$ infection. Among the three brothers sharing the same delivery conditions with exposure to the same virus, as well as sharing the same environment after birth, HCV infection has not been consistent, and one of them possessing the TG genotype of the IL28B gene (rs8099917) has had chronic HCV infection. These cases suggest that maternal HCV transmission does not occur so often, even among multiple children who are exposed to the same HCV with a high viral load, and that this variation might be attributable to very minor events that can impact on viral exposure in the perinatal period.
\end{abstract}

Keywords: Hepatitis; HCV; Perinatal infection; Vertical infection; Interleukin 28B

Manuscript accepted for publication March 4, 2014

${ }^{a}$ Department of Gastroenterology, Yamagata University School of Medicine, Yamagata 990-9585, Japan

${ }^{\mathrm{b}}$ Public Health, Yamagata University School of Medicine, Yamagata 990-9585, Japan

${ }^{\mathrm{c} C o r r e s p o n d i n g ~ a u t h o r: ~ T a k a f u m i ~ S a i t o, ~ D e p a r t m e n t ~ o f ~}$

Gastroenterology, Yamagata University School of Medicine, 2-2-

2 Iida-nishi, Yamagata 990-9585, Japan.

Email: tasaitoh@med.id.yamagata-u.ac.jp

doi: http://dx.doi.org/10.14740/jmc1736w

\section{Introduction}

Mother-to-child transmission of hepatitis C virus (HCV) is a serious health problem, and no effective preventive vaccine has yet been developed. The mechanism and timing of mother-to-child HCV transmission are not understood, nor is the natural history of the infection in mothers and their children. The rate of $\mathrm{HCV}$ transmission from $\mathrm{HCV}$-infected mother to child is reported to be approximately $4-10 \%$ [1-7], but the associated factors are not fully defined [8].

$\mathrm{HCV}$ infection leads to development of chronic hepatitis with a risk of progression to cirrhosis and liver cancer, but some individuals clear the virus spontaneously and the hepatitis resolves in a self-limiting manner in the acute phase of infection [9-11]. Recently, it has been reported that the host genetic single nucleotide polymorphism (SNP) in the region of the interleukin $28 B$ (IL28B) gene encoding interferon- $\lambda-3$, rs12979860, is associated with spontaneous HCV clearance in adults $[12,13]$, and even in infants vertically infected with HCV from their mothers [14]. This SNP is in high linkage disequilibrium with rs8099917, as reported for Japanese subjects $[15,16]$. Furthermore, upstream of the $I L 28 B$ gene, a dinucleotide variant ss469415590 in the IFNL4 gene encoding interferon- $\lambda-4$ protein has been reported to be more strongly associated with $\mathrm{HCV}$ clearance, and this variant is in high linkage disequilibrium with the SNPs of IL28B [17]. Thus, these genetic markers are worth investigating further for their possible usefulness in predicting the outcome of maternal HCV infection in children.

The pattern of maternal HCV transmission in multiple children from the same mother is still unclear. There is little evidence to indicate whether mother-to-child transmission of $\mathrm{HCV}$ occurs evenly or unevenly in this situation. Such cases would be informative for understanding the risk of perinatal $\mathrm{HCV}$ infection. We have experienced three deliveries from the same HCV-monoinfected mother, and prospectively followed up the three children after birth. In all of them, the factors possibly related to maternal HCV transmission, namely, the gender of the children, birth weight, delivery conditions, a high viral titer in the mother before their births, positivity for anti-HCV antibody in their umbilical blood and their en- 


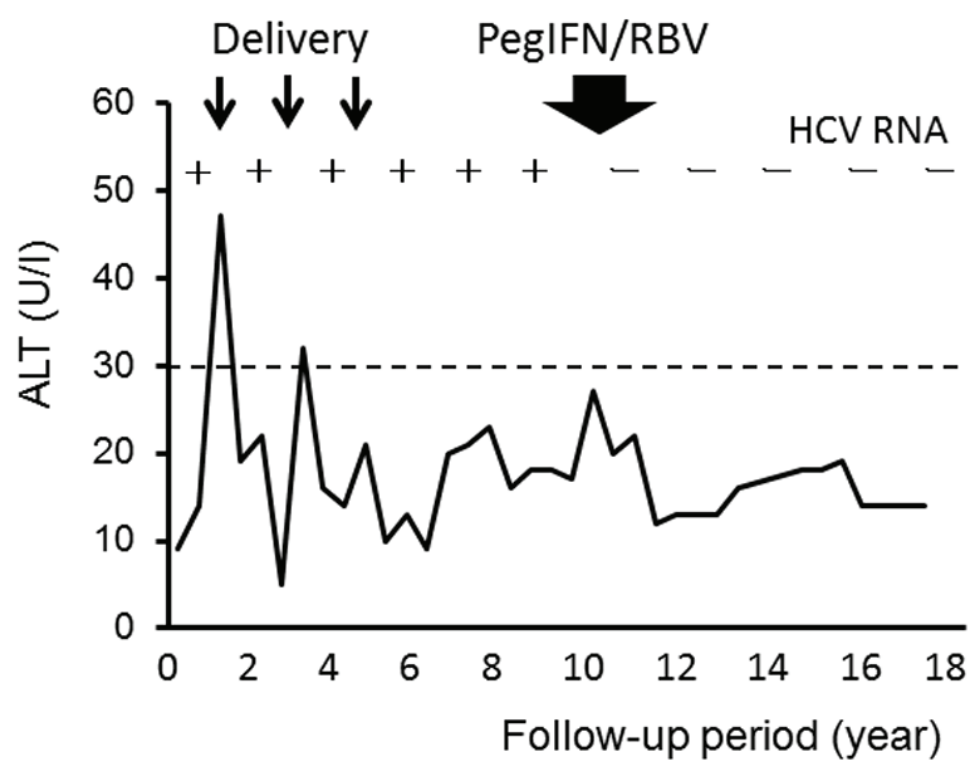

Figure 1. Clinical course and serum alanine aminotransferase (ALT) levels in the mother with chronic HCV genotype $2 b$ infection. Positivity and negativity for serum HCV RNA are represented as plus $(+)$ and minus (-), respectively. PegIFN/RBV: pegylated interferon plus ribavirin treatment.

vironment after birth were uniform.

Here, we report the results of HCV transmission in these three children born from the same mother infected with $\mathrm{HCV}$, with special reference to both the natural course of $\mathrm{HCV}$ infection in the children and their genotypes of $I L 28 B$ (rs8099917) and IFNL4 (ss469415590) associated with the outcome of infection.

\section{Case Report}

The mother has been followed up for hepatitis $\mathrm{C}$ at our hospital for 18 years. The long-term course of her HCV infection is shown in Fig. 1. The serum alanine aminotransferase (ALT) level was low, at under $30 \mathrm{U} / \mathrm{L}$, during the follow-up period except for two occasions when it exceeded $30 \mathrm{U} / \mathrm{L}$ just after delivery of the first and second sons. She had been infected with HCV genotype $2 b$, and the viral load was always high before she received antiviral therapy. Both hepatitis B surface antigen and anti-immunodeficiency virus antibody were negative in her serum. Six years after the third delivery, she received antiviral therapy with pegylated interferon plus ribavirin for chronic hepatitis $\mathrm{C}$ according to the Japanese standard protocol [18], and the therapy was successful in achieving a sustained virologic response.

The characteristics of the three children are summarized in Table 1. All were boys who were born by normal spontaneous delivery 40 weeks after the start of pregnancy. All were healthy and their birth weight was almost the same, at approximately $3,400 \mathrm{~g}$. Nothing in their history suggested any concern about contamination with $\mathrm{HCV}$ during their perinatal periods, namely, wounds, surgery or transfusion of blood products. Anti-HCV antibody in the umbilical blood was tested for at birth, and it was positive in all of them. The first and third sons had no evidence of HCV infection because neither anti-HCV antibody nor HCV RNA in serum was positive after birth. However, the second son was confirmed to be infected with HCV 108 days after the delivery showing positivity for both anti-HCV antibody and $\mathrm{HCV}$ RNA in serum by the first postnatal assay. HCV transmission to this child resulted in persistent infection. The long-term follow-up and clinical course of this HCV-infected child are shown in Fig. 2. The serum ALT level had been low, at under $30 \mathrm{U} / \mathrm{L}$, for approximately the first 2 years after birth, but thereafter fluctuated above and below $30 \mathrm{U} / \mathrm{L}$ until approximately 14 years of age. The HCV genotype of this child was $2 \mathrm{~b}$, which was the same as the mother's, and the high-level viremia has continued during the follow-up period. Although the factors possibly influencing maternal $\mathrm{HCV}$ transmission, namely, gender, birth weight, delivery conditions, the mother's high viral titer and positivity for anti-HCV antibody in the umbilical blood, were the same among the three siblings, HCV transmission from the mother occurred only in the second child. The genetic polymorphisms of the $I L 28 B$ gene (rs8099917) and IFNL4 gene (ss469415590) associated with spontaneous viral clearance were examined after obtaining written informed consent from their mother. The genotypes of the IL28B gene (rs8099917) and IFNL4 gene (ss469415590) in the second son, in whom persistent HCV infection had become established, were TG and $\Delta \mathrm{G} / \mathrm{TT}$, re- 
Table 1. Characteristics of Children Born From the HCV-Infected Mother

\begin{tabular}{|c|c|c|c|}
\hline & First child & Second child & Third child \\
\hline Sex & Male & Male & Male \\
\hline Delivery & NSD (39 weeks) & NSD (40 weeks) & NSD (40 weeks) \\
\hline Body weight at birth & $3,364 \mathrm{~g}$ & $3,492 \mathrm{~g}$ & $3,400 \mathrm{~g}$ \\
\hline $\begin{array}{l}\text { HCV RNA in mother's serum before } \\
\text { birth }\end{array}$ & 8.2 Meq/mL* & $6.0 \log \mathrm{IU} / \mathrm{mL}^{* *}$ & $40.0 \mathrm{Meq} / \mathrm{mL}^{*}$ \\
\hline Anti-HCV antibody in umbilical blood & Positive $(\mathrm{CI}>5.0)$ & Positive $(\mathrm{CI}>5.0)$ & Positive $(\mathrm{CI}>5.0)$ \\
\hline HCV RNA in umbilical blood & n.t. & $<0.5 \mathrm{Meq} / \mathrm{mL}^{*}$ & n.t. \\
\hline Anti-HCV antibody in serum after birth & Negative & Positive $(\mathrm{CI}>5.0)$ & Negative \\
\hline HCV RNA in serum after birth & Negative*** & Positive*** & Negative*** \\
\hline Persistent HCV viremia (period) & Not applicable & 15 years & Not applicable \\
\hline IL28B polymorphism (rs8099917) & TG & TG & TT \\
\hline IFNL4 polymorphism (ss469415590) & $\Delta \mathrm{G} / \mathrm{TT}$ & $\Delta \mathrm{G} / \mathrm{TT}$ & $\mathrm{TT} / \mathrm{TT}$ \\
\hline
\end{tabular}

NSD: normal spontaneous delivery; n.t.: not tested; Cl: cutoff index. ${ }^{* *}$ This assay was done using the preserved sample. HCV RNA was measured by *branched DNA assay, ${ }^{* *}$ real time PCR, ${ }^{* * *}$ qualitative PCR.

spectively. Those in the other children who were not infected with $\mathrm{HCV}$ varied, being TG and $\Delta \mathrm{G} / \mathrm{TT}$ in the first child, and TT and TT/TT in the third child.

\section{Discussion}

In this study, we observed different outcomes of HCV transmission among three brothers who had been exposed to the same HCV strain from the mother during the perinatal period. Interestingly, maternal $\mathrm{HCV}$ genotype $2 \mathrm{~b}$ transmission did not occur evenly in these three siblings, despite the fact that all had the same HCV exposure as well as upbringing environment, and only the second child was infected with HCV genotype $2 b$. This HCV transmission led to persistent infection in this child, in whom the genotypes of the $I L 28 B$ gene (rs8099917) and IFNL4 gene (ss469415590) were TG and $\Delta \mathrm{G} / \mathrm{TT}$, respectively, which are unfavorable for spontaneous viral clearance after the establishment of infection [13, 19].

It is still unclear how mother-to-child HCV transmission occurs in the perinatal period, and our present findings may help to shed some light on the route of infection. During the perinatal period, there are two possible major routes of $\mathrm{HCV}$ transmission from mother to child: placental infection and birth canal infection. Placental infection results from active transport of virus from mother to child, or from micro-transfusion of virus due to placental membrane damage. In all of the three brothers, blood exchange between the fetus and the mother through the placenta had been good, because antiHCV antibody (immunoglobulin G) had been transferred to all fetuses and was detected in the umbilical blood at birth in all cases. However, only the second child had been infected with HCV. Negativity for HCV RNA in the umbilical blood of this child was different from the viral titer in the serum of his mother, which indicated a very high level of HCV RNA, as shown in Table 1. Thus placental infection by active transport of $\mathrm{HCV}$ from mother to fetus appeared to have been negligible. Placental membrane damage possibly induced by a small wound that goes unnoticed at delivery may result in maternal $\mathrm{HCV}$ infection. In cases of twin delivery, $\mathrm{HCV}$ transmission is more likely to affect the second child because possible partial placental separation upon delivery of the first baby increases the chance of exposing the second 


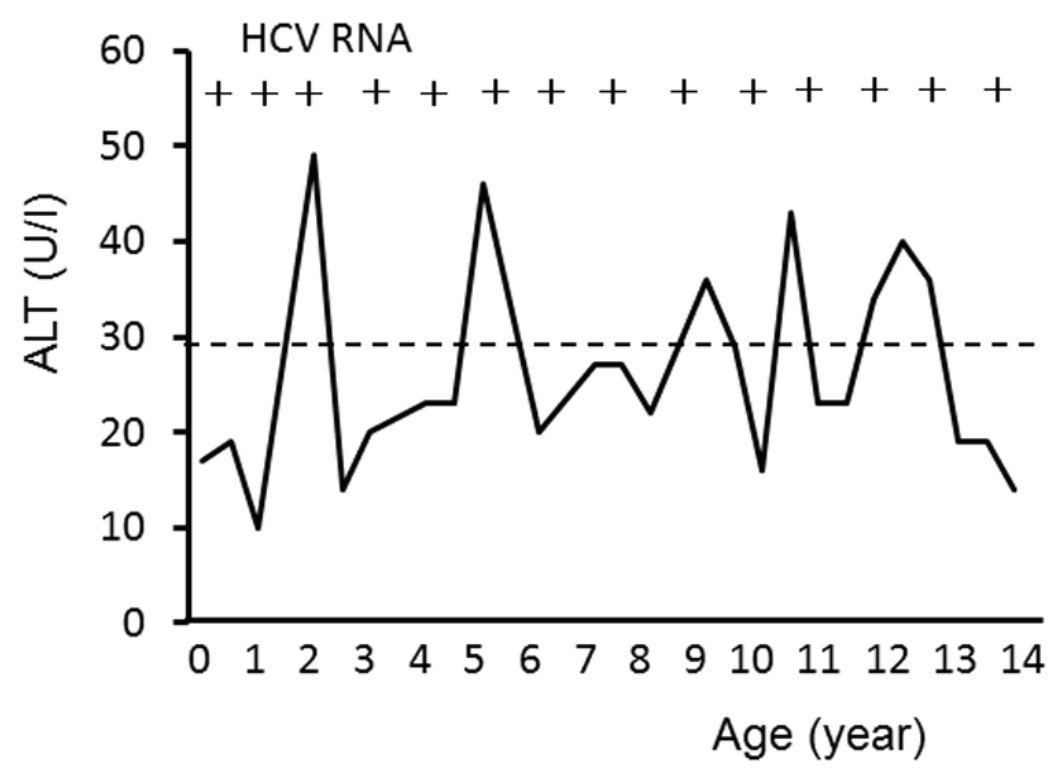

Figure 2. Long-term follow-up of serum alanine aminotransferase (ALT) levels in the second child with maternal HCV genotype $2 \mathrm{~b}$ infection. Positivity for serum HCV RNA is represented as plus (+).

child to maternal blood [20]. Otherwise, any small wound in child, such as on the skin or in the mucosa of the oral cavity, or the bulbar conjunctiva, may allow micro-transfusion of $\mathrm{HCV}$ from mother to a child, and this may result in maternal HCV transmission in the birth canal. After birth, the present three brothers were brought up in the same environment, and were breast-fed. This kind of background carries little risk of HCV infection [21]. These findings suggest that maternal HCV transmission does not usually occur in the perinatal period, with only rare exceptions due to accidental exposure such as minor placental damage or micro-wounds in the child. The prevalence of maternal HCV infection seems to be relatively low even among children exposed to the same virus, although serologic tests for $\mathrm{HCV}$ in children should be carefully conducted during follow-up.

Most adults with HCV infection fail to clear the virus and develop chronic hepatitis, but some are known to show resolution of the infection in a self-limiting manner. The rate of spontaneous viral clearance in the acute phase of infection is reported to be approximately $15-40 \%$ of all HCV-infected adults [9-11], and a systematic review of 31 studies has estimated this rate to be $26 \%$ [11]. In a recent genome-wide association study, the SNPs in the region of the $I L 28 B$ gene encoding interferon- $\lambda-3$ were shown to be associated with the virologic response of HCV to antiviral therapy $[15,22]$. Patients carrying an IL28B homozygote for the major alleles of rs12979860 (CC genotype) [22] or rs8099917 (TT genotype) [15] show a greater propensity for achieving a sustained virologic response to pegylated interferon- $\alpha$ and ribavirin therapy than those carrying an $I L 28 B$ heterozygote or homozygote for its minor allele. This SNP (rs12979860) also influences the outcome of HCV infection in the context of natural history; the CC genotype of rs12979860, which is in high linkage disequilibrium with the TT genotype of rs8099917, enhances the resolution of HCV infection with spontaneous clearance [12, 13]. Furthermore, upstream of the IL28B gene, a dinucleotide variant ss469415590 (TT or $\triangle \mathrm{G})$ has been reported to be more strongly associated with $\mathrm{HCV}$ clearance in individuals of African ancestry than the SNP of IL28B (rs12979860) [17].

The genotype of $I L 28 B$ is also associated with the outcome of infection in maternal HCV transmission; self-limiting hepatitis or persistent hepatitis has been reported in a child infected with HCV genotype 1 during the perinatal period [14]. The three children in the present report were checked for the SNPs of both the IL28B (rs8099917) and IFNL4 (ss469415590) genes, and the second son in whom $\mathrm{HCV}$ genotype $2 \mathrm{~b}$ infection had been established and led to persistent infection with mild fluctuation of the ALT levels was found to carry the TG (rs8099917) type and $\Delta \mathrm{G} /$ TT (ss469415590) type in the IL28B and IFNL4 genes, respectively. Thus the SNPs in these two genes predicted the outcome of infection in the second son with chronic $\mathrm{HCV}$ genotype $2 b$ infection.

In conclusion, our present findings suggest that the chance of maternal HCV transmission is not so high even in multiple children exposed to the same HCV strain with a high viral load, and that maternal HCV transmission might be attributable to very minor events that can potentially result in viral exposure during the perinatal period. Here, the multiple deliveries did not largely affect the serum levels of ALT and HCV RNA in the mother. The genotype defined by 
SNPs in the IL28B gene (rs8099917) and the IFNL4 gene (ss469415590) was able to predict the development of persistent infection in the child with established maternal HCV genotype $2 b$ transmission.

\section{Conflict of Interest}

The authors have no conflict of interest.

\section{References}

1. Ohto H, Terazawa S, Sasaki N, Hino K, Ishiwata C, Kako M, Ujiie N, et al. Transmission of hepatitis C virus from mothers to infants. The Vertical Transmission of Hepatitis C Virus Collaborative Study Group. N Engl J Med. 1994;330(11):744-750.

2. Matsubara T, Sumazaki R, Takita H. Mother-to-infant transmission of hepatitis $\mathrm{C}$ virus: a prospective study. Eur J Pediatr. 1995;154(12):973-978.

3. Zanetti AR, Tanzi E, Paccagnini S, Principi N, Pizzocolo G, Caccamo ML, D'Amico E, et al. Motherto-infant transmission of hepatitis $\mathrm{C}$ virus. Lombardy Study Group on Vertical HCV Transmission. Lancet. 1995;345(8945):289-291.

4. Resti M, Azzari C, Mannelli F, Moriondo M, Novembre E, de Martino M, Vierucci A. Mother to child transmission of hepatitis $\mathrm{C}$ virus: prospective study of risk factors and timing of infection in children born to women seronegative for HIV-1. Tuscany Study Group on Hepatitis C Virus Infection. BMJ. 1998;317(7156):437-441.

5. Gibb DM, Goodall RL, Dunn DT, Healy M, Neave P, Cafferkey M, Butler K. Mother-to-child transmission of hepatitis $\mathrm{C}$ virus: evidence for preventable peripartum transmission. Lancet. 2000;356(9233):904-907.

6. Dal Molin G, D'Agaro P, Ansaldi F, Ciana G, Fertz C, Alberico S, Campello C. Mother-to-infant transmission of hepatitis $\mathrm{C}$ virus: rate of infection and assessment of viral load and IgM anti-HCV as risk factors. J Med Virol. 2002;67(2):137-142.

7. Steininger C, Kundi M, Jatzko G, Kiss H, Lischka A, Holzmann H. Increased risk of mother-to-infant transmission of hepatitis $\mathrm{C}$ virus by intrapartum infantile exposure to maternal blood. J Infect Dis. 2003;187(3):345351.

8. Cottrell EB, Chou R, Wasson N, Rahman B, Guise JM. Reducing risk for mother-to-infant transmission of hepatitis C virus: a systematic review for the U.S. Preventive Services Task Force. Ann Intern Med. 2013;158(2):109113.

9. Di BisceglieAM. Natural history of hepatitis C: its impact on clinical management. Hepatology. 2000;31(4):1014-
1018.

10. Gerlach JT, Diepolder HM, Zachoval R, Gruener NH, Jung MC, Ulsenheimer A, Schraut WW, et al. Acute hepatitis C: high rate of both spontaneous and treatment-induced viral clearance. Gastroenterology. 2003;125(1):80-88.

11. Micallef JM, Kaldor JM, Dore GJ. Spontaneous viral clearance following acute hepatitis $\mathrm{C}$ infection: a systematic review of longitudinal studies. J Viral Hepat. 2006;13(1):34-41.

12. Thomas DL, Thio CL, Martin MP, Qi Y, Ge D, O'Huigin C, Kidd J, et al. Genetic variation in IL28B and spontaneous clearance of hepatitis $\mathrm{C}$ virus. Nature. 2009;461(7265):798-801.

13. Hung CH, Chang KC, Lu SN, Wang JH, Chen CH, Lee $\mathrm{CM}, \mathrm{Hu} \mathrm{TH}$. Spontaneous clearance of hepatitis $\mathrm{C}$ virus in an interleukin 28B favorable genotype highly prevalent area. Hepatology. 2013;57(5):2089-2090.

14. Ruiz-Extremera A, Munoz-Gamez JA, Salmeron-Ruiz MA, de Rueda PM, Quiles-Perez R, Gila-Medina A, Casado J, et al. Genetic variation in interleukin 28B with respect to vertical transmission of hepatitis $\mathrm{C}$ virus and spontaneous clearance in HCV-infected children. Hepatology. 2011;53(6):1830-1838.

15. Tanaka Y, Nishida N, Sugiyama M, Kurosaki M, Matsuura K, Sakamoto N, Nakagawa M, et al. Genome-wide association of IL28B with response to pegylated interferon-alpha and ribavirin therapy for chronic hepatitis $\mathrm{C}$. Nat Genet. 2009;41(10):1105-1109.

16. Balagopal A, Thomas DL, Thio CL. IL28B and the control of hepatitis $\mathrm{C}$ virus infection. Gastroenterology. 2010;139(6):1865-1876.

17. Prokunina-Olsson L, Muchmore B, Tang W, Pfeiffer RM, Park H, Dickensheets H, Hergott D, et al. A variant upstream of IFNL3 (IL28B) creating a new interferon gene IFNL4 is associated with impaired clearance of hepatitis C virus. Nat Genet. 2013;45(2):164-171.

18. Guidelines for the Management of Hepatitis C Virus Infection: First edition, May 2012, The Japan Society of Hepatology. Hepatol Res. 2013;43(1):1-34.

19. Saito T, Ueno Y. Transmission of hepatitis $C$ virus: selflimiting hepatitis or chronic hepatitis? World J Gastroenterol. 2013;19(41):6957-6961.

20. Boxall E, Baumann K, Price N, Sira J, Brown M, Kelly D. Discordant outcome of perinatal transmission of hepatitis C in twin pregnancies. J Clin Virol. 2007;38(2):9195.

21. Indolfi G, Resti M. Perinatal transmission of hepatitis $C$ virus infection. J Med Virol. 2009;81(5):836-843.

22. Ge D, Fellay J, Thompson AJ, Simon JS, Shianna KV, Urban TJ, Heinzen EL, et al. Genetic variation in IL28B predicts hepatitis $\mathrm{C}$ treatment-induced viral clearance. Nature. 2009;461(7262):399-401. 